\title{
Soil carbon and nitrogen stocks, light organic matter, and remaining phosphorus under a crop-livestock integration system
}

\author{
Estoques de carbono e nitrogênio, matéria orgânica leve e fósforo \\ remanescente do solo sob sistema de integração lavoura-pecuária
}

\author{
Wanderlei Bieluczyk ${ }^{1 *}$; Marcos Gervasio Pereira²; \\ Roni Fernandes Guareschi; João de Andrade Bonetti'; \\ Geanderson Nascimento da Silva ${ }^{5}$; Eduardo Carvalho da Silva Neto ${ }^{6}$
}

\begin{abstract}
Crop-livestock integration (CLI) is a management system that has been developed for a variety of soil and climatic conditions, which combined with the no-tillage system (NTS), has many variations in Brazil, particularly regarding grazing intensity. The objective of this study was to assess the effects of different grazing intensities and soybean (Glycine max L.) crops on carbon (Cst) and nitrogen (Nst) stocks, light organic matter (LOM), root content of the LOM (RLOM), and remaining phosphorus (Prem) in an Oxisol under CLI. The treatments consisted of three different heights $(0.25 \mathrm{~m}$ [P25], $0.35 \mathrm{~m}$ [P35], and $0.45 \mathrm{~m}$ [P45]) of pasture grown in a CLI system. Two control areas, an area without grazing (AWG) and a native vegetation area of the Cerrado biome (NCA), which were adjacent to the experimental area, were compared with the cultivated areas. Soil samples were collected from $0.00-0.05,0.05-0.10$, and $0.10-0.20 \mathrm{~m}$ beneath each area in a completely randomized design with six replications. Soil characteristics were evaluated in the post-pasture cycle period (PP) and the postsoybean crop period (PC), which coincided with the wet and dry seasons, respectively. The NCA had more LOM in the 0.00-0.05 m layer during the PC and the 0.05-0.10 m layer during both the PP and the $\mathrm{PC}, \mathrm{C}$ in the LOM in the $0.00-0.20 \mathrm{~m}$ layer during the PP and the PC, $\mathrm{N}$ in the LOM in the $0.00-0.05 \mathrm{~m}$ layer in the PC and the 0.05-0.10 m layer in the PP and the PC, and Cst in the $0.00-0.20 \mathrm{~m}$ layer in the $\mathrm{PP}$ and the PC than the cultivated areas, but a lower soil density (SD) and Prem in the 0.00-0.20 m layer during both the PP and the PC. Treatment P35 had more Nst in the PC and RLOM in the PP than the other cultivated treatments and the AWG. The absence of grazing in the AWG decreased the SD from the PP to the PC, while the treatments with different grazing intensities had similar values throughout this period. Our results suggest that production could be intensified under light and moderate grazing intensities in the CLI system.
\end{abstract}

Key words: No-tillage system. Grazing intensity. Soil organic matter. Cerrado biome.

\footnotetext{
${ }^{1}$ Discente Curso de Doutorado, Programa de Pós-Graduação em Ciências, Energia Nuclear na Agricultura, Laboratório de Ciclagem de Nutrientes, Centro de Energia Nuclear na Agricultura, Universidade de São Paulo, CENA/USP, Piracicaba, SP, Brasil. E-mail: wanderleibieluczyk@gmail.com

2 Prof. Dr., Departamento de Solos, Universidade Federal Rural do Rio de Janeiro, UFRRJ, Seropédica, RJ, Brasil. E-mail: mgervasiopereira@gmail.com

${ }_{3}^{3}$ Pós-Doutorado em Fitotecnia, Departamento de Fitotecnia, UFRRJ, Seropédica, RJ, Brasil. E-mail: guareschiecotarelli@hotmail. com

${ }^{4}$ Discente do Curso de Doutorado do Programa de Pós-Graduação em Agronomia: Ciência do Solo, UFRGS, Porto Alegre, RS, Brasil. E-mail: agro.bonetti@gmail.com

5 Prof. Dr., Instituto Federal de Educação, Ciência e Tecnologia do Sertão Pernambucano, IF Sertão, PE, Petrolina, PE, Brasil. E-mail: gean.tecnologo@hotmail.com

${ }^{6}$ Discente Curso de Mestrado, Programa de Pós-Graduação em Agronomia, Ciência do Solo, UFRRJ, Seropédica, RJ, Brasil. E-mail: netocseduardo@gmail.com

* Author for correspondence
} 


\section{Resumo}

A integração lavoura-pecuária (ILP), combinada ao sistema plantio direto (SPD), é um sistema de manejo que tem sido desenvolvido para diversas condições edafoclimáticas, com muitas variações no Brasil, principalmente quanto a intensidade de pastejo. O objetivo deste estudo foi avaliar os efeitos de diferentes intensidades de pastejo e cultivo da soja (Glycine max L.) nos estoques de carbono (EstC) e nitrogênio (EstN), matéria orgânica leve (MOL), conteúdo de raízes na MOL (RMOL) e fósforo remanescente (Prem) em um Latossolo sob ILP. Os tratamentos consistiram em três diferentes alturas de manejo do pasto na ILP (0,25 m [P25], 0,35 m [P35], e 0,45 m [P45]). Duas áreas de controle, uma sem pastejo (SP) e uma área de vegetação nativa de cerrado (cerradão) (CE), que estiveram adjacentes ao experimento, foram comparadas com as áreas cultivadas. Em cada área as amostras foram coletadas nas camadas de $0,0-0,05 ; 0,05-0,10$ e $0,10-0,20 \mathrm{~m}$ em delineamento inteiramente aleatorizado com 6 repetições. Os atributos do solo foram avaliados pós-ciclo de pastejo (PP) e pós-lavoura de soja (PL), que coincidiram com as estações seca e chuvosa, respectivamente. O CE apresentou maiores conteúdos de MOL na camada 0,0-0,05 m na PL e na camada 0,05-0,10 m em ambas épocas PP e PL, C na MOL na camada $0,0-0,020 \mathrm{~m}$ durante o PP e a PL, N na MOL na camada $0,0-0,05 \mathrm{~m}$ na PL e na camada 0,05-0,10 m durante o PP e a PL, EstC na camada de 0,0-0,020 m em ambos PP e PL em relação às áreas cultivadas, entretanto menores valores de densidade do solo (Ds) e Prem na camada de 0,0-0,020 $\mathrm{m}$ durante o PP e a PL. O tratamento (P35) incrementou EstN na PL e RMOL no PP em relação aos outros cultivos P25, P45 e SP. A ausência de pastejo da área SP reduziu a Ds do PP para a PL, enquanto os tratamentos com diferentes intensidades de pastejo mantiveram estabilizados seus valores neste período. Os nossos resultados sugerem que a produção pode ser intensificada sob intensidades baixa e moderada de pastejo na ILP avaliada.

Palavras-chave: Sistema de plantio direto. Intensidade de pastejo. Matéria orgânica do solo. Cerrado.

\section{Introduction}

Many variations of the crop-livestock integration (CLI) system have been used in Brazil. Grazing intensity affects the amount of plant residues that are left by the off-season crop to ensure sufficient straw contents for the following crop in the summer season using the no-tillage system (NTS) (BIELUCZYK, 2014; BONETTI et al., 2015). The success of the CLI system is also dependent on crop rotation and crop and pasture species (CARVALHO et al., 2010). The most suitable CLI conditions are strictly related to the edaphoclimatic conditions of the region (LEMAIRE et al., 2014; SALTON et al., 2014). Previous studies have evaluated several soil quality indicators in the Cerrado biome, including the light organic matter (LOM) content (LOSS et al., 2011, 2012a), carbon (Cst) and nitrogen (Nst) stocks (SOUZA et al., 2009; GAZOLLA et al., 2013), soil density (SD) (FLORES et al., 2007; CONTE et al., 2011; BONETTI et al., 2015), and remaining phosphorus (Prem) (BIELUCZYK, 2014; BEUTLER et al., 2015; BEZERRA et al., 2015), and have compared different CLI systems and/or grazing intensities with areas without grazing and/ or native vegetation.

However, few studies have evaluated LOM dynamics under CLI in the Cerrado. Loss et al. (2011, 2012a) evaluated different management systems in this biome, and observed constant renewal of the grass root system in CLI areas, which favored the input of root residues in subsurface layers that resulted in an amount of LOM equivalent to that produced by the native Cerrado, and higher than that produced in the NTS area (without intercropping and rotation with grasses). Therefore, studies that assess the amount of LOM and the contribution of roots to LOM formation in CSI systems are essential.

Soil Cst and Nst under CLI tend to increase over time, and, sometimes, even equalize and exceed the values found in native Cerrado vegetation areas (NCA) and areas with NTS without grazing (SOUZA et al., 2009; LOSS et al., 2012b; GAZOLLA et al., 2013). This increase is caused by a combination of several factors, such as high 
shoot and root production by grasses, cattle manure, deposition of plant residues from annual crops, and fertilization (SOUZA et al., 2009; LOSS et al., 2012c). However, the grazing intensity to be applied must be planned under CLI, because high grazing intensities decrease Cst and Nst, depending on the organic matter degradation (SOUZA et al., 2009).

Increases in SD that are related to animal trampling is another factor to considerinCLI systems. Different results have been obtained by previous studies regarding this issue, including increases in SD (FLORES et al., 2007; LANZANOVA et al., 2007) and an absence of animal trampling and/ or grazing intensity effects (CONTE et al., 2011; BONETTI et al., 2015). Therefore, the SD requires further study in CLI areas, because other variables, such as Cst and root development during the grazing phase, influence the physical characteristics of the soil, depending on the system implemented.

Changes in soil organic matter (SOM) dynamics and nutrient cycling that result from the adoption of NTS and CLI alter the soil's maximum phosphorus (P) adsorption capacity (BEZERRA et al., 2015; GUARESCHI et al., 2015). Prem is closely related to soil P adsorption (ALVAREZ et al., 2000), with low values in highly weathered soils and/or in soils with low SOM contents (CAMARGO et al., 2010). Prem indicates $P$ availability (ALVAREZ et al., 2000), and is used for the application of phosphate fertilizers (VALLADARES et al., 2003). CLI increased the soil Prem in Montevidiu, which is in the Cerrado biome of Goiás (BEZERRA et al., 2015); a CLI area had higher Prem values in the 0.0$0.10 \mathrm{~m}$ soil layer than a NTS area (without grazing), mainly because of higher dry mass input in the CLI system. The authors also reported that grazing may had increased the blocking of soil $\mathrm{P}$ adsorption sites by light molecular-weight organic acids from SOM.

Several studies have been conducted on CLI, but investigations of the changes caused by different grazing intensities on SOM dynamics and related variables are still needed. Dry root biomass quantification can also determine SOM quantity, quality, and cycling in the CLI system. Therefore, the objective of this study was to assess the effects of different grazing intensities and soybean (Glycine $\max$ L.) crops on Cst and Nst, LOM content, root content in the LOM (RLOM), and Prem in an Oxisol under CLI.

\section{Material and Methods}

The experiment was conducted in the experimental area of the Goias Federal University, Jatai campus (17'56'S, 51 $43^{\circ} \mathrm{W}$ and $800 \mathrm{~m}$ above mean sea level). The soil of the region is classified as Oxisol (typical distroferric Red Latosol [SiBCS]), with slightly rugged terrain (EMBRAPA, 2013; BONETTI et al., 2015).

The region's climate is tropical wet (Aw) according to the Köppen classification, and has two defined seasons, wet (October to April) and dry (May to September). The region has an annual average temperature of $22^{\circ} \mathrm{C}$ and an annual average precipitation of $1600 \mathrm{~mm}$. The monthly average temperatures and precipitation of the 2012/2013 crop season are shown in Figure 1.

The area has a high degradation level, low plant production, and weeds due to inadequate grass (Brachiaria decumbens) management and grazing that had been conducted for 20 years before the experiment.

Soil liming with dolomitic limestone (2.5 magnesium [Mg] ha-1 ${ }^{-1}$ TNP $80 \%$ ) was conducted in May 2009 to raise the base saturation to $60 \%$. The lime was incorporated into the soil by plowing once and harrowing twice. Another liming with dolomitic limestone (2.3 $\mathrm{Mg} \mathrm{ha}^{-1}$, TNP $80 \%$ ) applied to the soil surface was conducted in the 2011/2012 crop season, based on soil chemical analysis, to raise the base saturation to $60 \%$ (Figure 2).

Plants in the experimental area were desiccated in October 2009 using glyphosate (4.0 L ha-1). Soybean was sowed with $0.45 \mathrm{~m}$ between rows and at a density of approximately 340,000 plants $\mathrm{ha}^{-1}$. Fertilization was performed using $350 \mathrm{~kg} \mathrm{ha}^{-1}$ nitrogen:phosphorous:potassium (NPK) $(2: 18: 18)$. 
Pesticides (herbicides, insecticides, and fungicides) undertaken in early February each year, due to the were applied as required. Harvesting was usually soybeans' early maturation.

Figure 1. Average monthly precipitation and temperature in the 2012/2013 crop season.

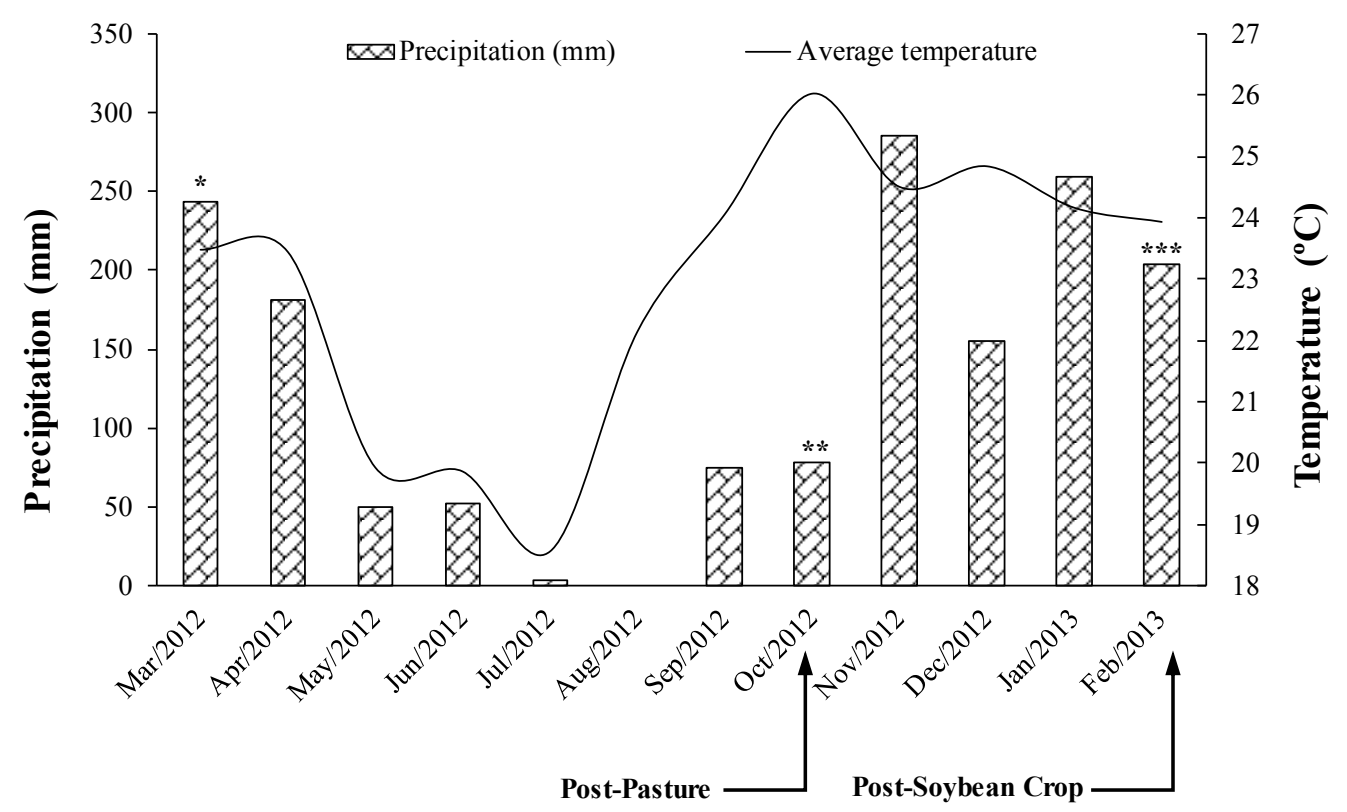

*Urochloa ruziziensis seed sowing; **Soybean sowing; ***Soybean harvest. Note: post-pasture cycle period and post-soybean crop period arrows indicate when the soil samples were taken.

Source: INMET Weather Station of Jatai (N. 83464).

Figure 2. Land-use history of the experimental areas and timing of the liming and sampling. P25, $0.25 \mathrm{~m}$; P35, 0.35 $\mathrm{m}$; and P45, $0.45 \mathrm{~m}$. AWG, control areas without grazing; NCA, areas with native vegetation (Cerrado biome).

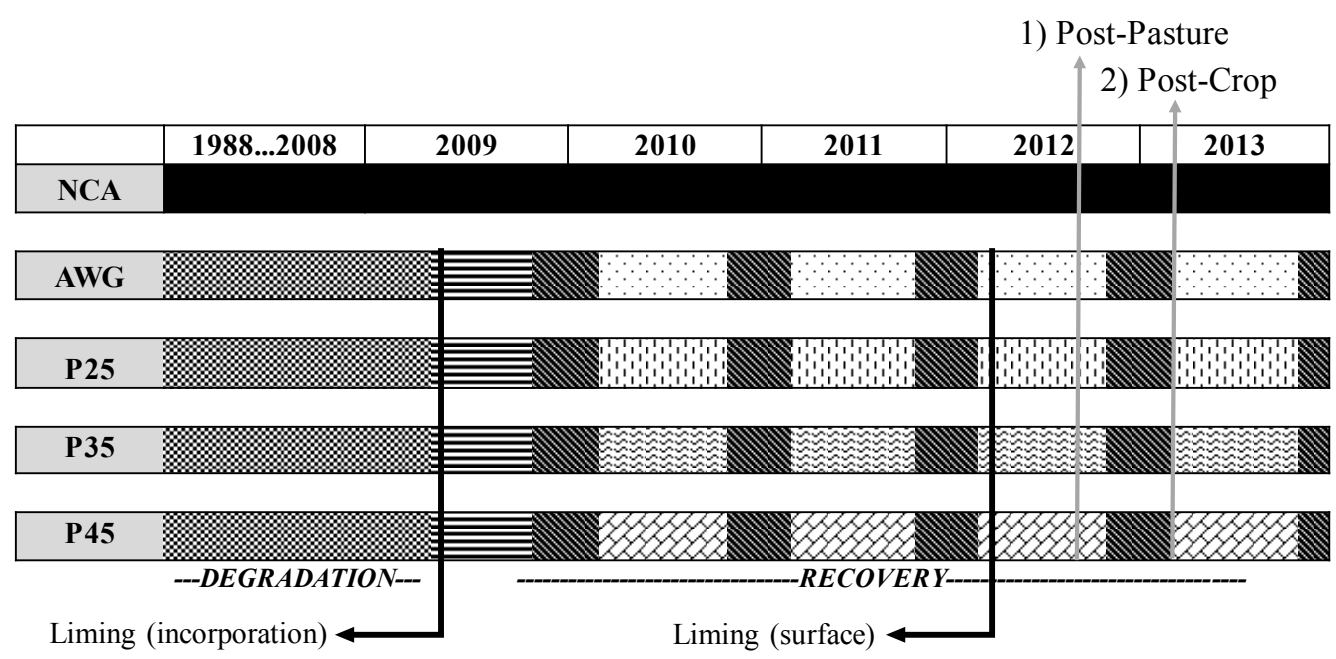

Native Vegetation of Cerrado Biome

Degraded Pasture

Implementation Period

Soybeans (Glycine max L.)

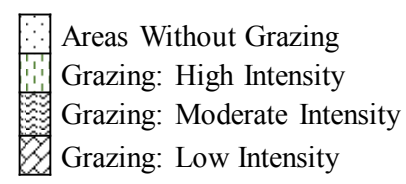


Urochloa ruziziensis seeds were sown in rows (10 $\mathrm{kg} \mathrm{ha}^{-1}$; germination index of $\left.65 \%\right)$ by direct seeding. About 45 days after the plants' emergence, $150 \mathrm{~kg} \mathrm{ha}^{-1} \mathrm{~N}$ (urea) was applied. Electric fences were installed around the area in June, and grazing started in July, 95 days after the emergence of $U$. ruziziensis.

Each year, grazing started in the winter, followed by the summer crop (soybean) (Figure 2). The total experimental area was approximately 22 ha, which was divided into 2.0-ha experimental plots in a randomized design with six replications.

The treatments consisted of three different pasture heights: $0.25 \mathrm{~m}$ (P25, high grazing intensity), $0.35 \mathrm{~m}$ (P35, moderate grazing intensity), and 0.45 $\mathrm{m}$ (P45, low grazing intensity), with areas without grazing (AWG) as controls. A native vegetation area of the Cerrado biome (NCA) that was adjacent to the experimental area was used as an additional control area of reference for comparison with the cultivated areas. Soil sampling was conducted at random points within this area, with a delimited plot $\left(10,000 \mathrm{~m}^{2}\right)$.

The animals were introduced to the pasture area when the average grass accumulation was approximately $4000 \mathrm{~kg}$ of dry biomass $\mathrm{ha}^{-1}$ with an average height of $1.03 \mathrm{~m}$. Grazing started in July and finished in mid-October, totaling 120 days. The grazing system was continuous, starting with animals with the average weight of 1 animal unit $(\mathrm{AU}=450 \mathrm{~kg})(\mathrm{BONETTI}$ et al., 2015). The animal densities were 1.5 (P25), 2.5 (P35), and 3.5 (P45) AU $\mathrm{ha}^{-1}$. The pasture height of the different treatments was monitored every 14 days using a sward stick, at 50 points in each plot. The desired pasture heights were obtained approximately 20 days after the cattle were introduced, which were then removed in order to maintain the pasture heights of each treatment.
Eighteen trenches were excavated in each area (P25, P35, P45, AWG, and NCA) and six composite soil samples were collected, each one consisting of three single samples. Soil sampling was performed on one wall of each trench from the 0.00-0.05, $0.05-0.10$, and $0.10-0.20 \mathrm{~m}$ layers. The samples were dried, disaggregated, and sieved through a 2-mm mesh sieve to obtain air-dried ground soil (ADGS) for the characterization of soil fertility and granulometry (DONAGEMA et al., 2011) (Table 1). The RLOM was evaluated in a soil monolith sample of $0.05 \times 0.20 \times 0.10 \mathrm{~m}$ (width $\mathrm{x}$ length $\mathrm{x}$ depth). The monolith was used to collect a sample from each trench at the 0.00-0.10 m layer, with no composite samples $(\mathrm{n}=18)$. The space between the $U$. ruziziensis and soybean rows was $0.45 \mathrm{~m}$; thus, the monolith width was about half of the space between rows $(0.2 \mathrm{~m})$. Therefore, root samples were collected from the $U$. ruziziensis and soybean rows towards the center of the spaces between the rows, which was representative.

Two soil samplings were conducted, one after cattle grazing (October 2012) and the other when the soybeans were at physiological maturity (February 2013), in order to investigate the effects of the livestock and crop managements on the variables evaluated (Figure 2). Samplings in the NCA were conducted at the same time as those conducted in the areas under cultivation, both in the dry (October 2012) and wet (February 2013) seasons (Figure 1).

The SD was evaluated using the volumetric ring method (DONAGEMA et al., 2011), and C and $\mathrm{N}$ contents were measured by dry combustion using a CHNS elemental analyzer (Elementar Analysensysteme $\mathrm{GmbH}$, Hanau, Germany). The C, N, and SD data were used to determine the Cst and Nst by the equivalent mass method (SISTI et al., 2004) using the soil mass of the Cerrado biome area as a reference, which represented the original condition of the soil. 
Table 1. Chemical and granulometric analysis of soil samples collected in the post-pasture period in areas subjected to different grazing intensities (P25, $0.25 \mathrm{~m} ; \mathrm{P} 35,0.35 \mathrm{~m}$; and P45, $0.45 \mathrm{~m}$ ) and control areas without grazing (AWG) and areas with native vegetation (Cerrado biome) (NCA).

\begin{tabular}{|c|c|c|c|c|c|c|c|c|c|c|c|c|}
\hline \multirow{2}{*}{ Area } & \multicolumn{2}{|c|}{$\mathrm{pH}$} & & $\mathrm{Ca}$ & $\mathrm{Mg}$ & $\mathrm{K}$ & $\mathrm{H}+\mathrm{Al}$ & $\mathrm{T}$ & \multirow{2}{*}{$\begin{array}{c}\mathrm{V} \\
--\%-- \\
\end{array}$} & Clay & Silt & Sand \\
\hline & $\mathrm{H}_{2} \mathrm{O}$ & $\mathrm{mg} \mathrm{kg}^{-1}$ & & \multicolumn{5}{|c|}{ - } & & \multicolumn{3}{|c|}{--------- g kg $^{-1}$-------- } \\
\hline & \multicolumn{12}{|c|}{$0.00-0.05 \mathrm{~m}$} \\
\hline $\mathrm{NCA}$ & 5.16 & 1.06 & 0.90 & 0.86 & 0.19 & 5.21 & 7.17 & 27 & 394 & 257 & & 349 \\
\hline AWG & 6.17 & 3.60 & 2.89 & 1.86 & 0.33 & 2.99 & 8.09 & 61 & 411 & 251 & & 338 \\
\hline P25 & 5.95 & 2.91 & 2.37 & 1.45 & 0.28 & 3.84 & 7.95 & 51 & 442 & 224 & & 334 \\
\hline P35 & 6.09 & 2.88 & 2.69 & 1.73 & 0.47 & 3.68 & 8.58 & 56 & 417 & 245 & & 338 \\
\hline \multirow[t]{2}{*}{ P45 } & 5.85 & 1.06 & 2.08 & 1.21 & 0.23 & 4.26 & 7.78 & 45 & 414 & 248 & & 338 \\
\hline & \multicolumn{12}{|c|}{$0.05-0.10 \mathrm{~m}$} \\
\hline NCA & 5.19 & 0.80 & 0.43 & 0.43 & 0.09 & 5.68 & 6.65 & 14 & 416 & 226 & & 358 \\
\hline AWG & 5.58 & 1.00 & 1.25 & 0.85 & 0.07 & 4.25 & 6.43 & 34 & 444 & 221 & & 335 \\
\hline P25 & 5.50 & 1.39 & 1.29 & 1.09 & 0.07 & 4.72 & 7.18 & 33 & 448 & 215 & & 337 \\
\hline P35 & 5.42 & 1.48 & 1.26 & 0.96 & 0.10 & 4.92 & 7.24 & 31 & 442 & 222 & & 336 \\
\hline \multirow[t]{2}{*}{ P45 } & 5.54 & 1.02 & 1.20 & 0.78 & 0.06 & 4.85 & 6.90 & 29 & 443 & 226 & & 331 \\
\hline & \multicolumn{12}{|c|}{$0.10-0.20 \mathrm{~m}$} \\
\hline NCA & 5.47 & 0.51 & 0.31 & 0.36 & 0.07 & 5.43 & 6.19 & 12 & 386 & 266 & & 349 \\
\hline AWG & 5.37 & 0.56 & 0.80 & 0.55 & 0.05 & 4.33 & 5.74 & 24 & 400 & 251 & & 349 \\
\hline P25 & 5.33 & 0.60 & 0.81 & 0.54 & 0.04 & 4.20 & 5.60 & 24 & 444 & 233 & & 323 \\
\hline P35 & 5.43 & 0.60 & 0.71 & 0.53 & 0.05 & 4.23 & 5.51 & 22 & 447 & 219 & & 335 \\
\hline P45 & 5.48 & 0.62 & 0.73 & 0.65 & 0.04 & 4.21 & 5.64 & 25 & 429 & 229 & & 343 \\
\hline
\end{tabular}

The LOM content in the $0.00-0.05 \mathrm{~m}$ and $0.05-$ $0.10 \mathrm{~m}$ layers was determined by the water flotation method (ANDERSON; INGRAM, 1989) by adding $100 \mathrm{~mL} \mathrm{NaOH}$ solution $\left(0.1 \mathrm{~mol} \mathrm{~L}^{-1}\right)$ to $50 \mathrm{~g}$ ADGS in a 0.25 -L beaker and leaving it to rest for $12 \mathrm{~h}$. The suspension was then stirred with a glass rod, and the material was sieved through a $0.25-\mathrm{mm}$ mesh sieve to remove the clay fraction. The material that remained on the sieve (LOM and sand) was transferred back to the beaker, and water was added to resuspend the LOM. The floating material was carefully sieved through a $0.25-\mathrm{mm}$ mesh sieve to separate the LOM from the sand fraction. Water was then added to the beaker, and the solution was manually stirred to resuspend the remaining LOM and slowly poured through a $0.25-\mathrm{mm}$ sieve. This process was repeated until all of the floating material had been collected. The material that remained on the sieve (LOM) was quantified after drying in an oven at $65^{\circ} \mathrm{C}$ until it was of constant weight ( $72 \mathrm{~h})$. For the analysis of elemental $\mathrm{C}$ and $\mathrm{N}$, approximately $5 \mathrm{~g}$ of soil was macerated and passed through a $0.149-\mathrm{mm}$ sieve (100 mesh). Subsequently, C and N contents were quantified by the dry combustion method using a $\mathrm{C}$ and $\mathrm{N}$ auto-analyzer (CHN-600 Carlo Erba EA1110 , Italy) at $900^{\circ} \mathrm{C}$.

The soil monolith samples that were collected for determining the RLOM were subjected to the LOM flotation process for subsequent quantification of the roots present in them. This procedure was conducted as follows: a $1-\mathrm{dm}^{-3}$ sample of the soil monolith was manually disaggregated in a $10-\mathrm{L}$ container, and the LOM was separated by the repetitive flotation process in water without dispersant. The floating material was passed through a set of sieves of decreasing mesh diameter (2.0, 1.0 , and $0.5 \mathrm{~mm}$ ), and carefully washed to separate the soil that was still in the sieves. The flotation process was performed again using $1.0-$ and $0.5-\mathrm{mm}$ mesh sieves, and the material (LOM) obtained was placed in Petri dishes and dried in a forced-air oven at $50^{\circ} \mathrm{C}$ for $72 \mathrm{~h}$; the total LOM was then weighed 
and quantified. One third of the samples (six simple samples per treatment) were manually separated using a magnifying glass, and the roots present in the LOM were dried in the oven and subsequently weighed, and the dry mass was quantified.

The Prem was determined by placing $5 \mathrm{~cm}^{3}$ ADGS in contact with $0.01 \mathrm{~mol} \mathrm{~L}^{-1} \mathrm{CaCl}_{2}$ solution containing $60 \mathrm{mg} \mathrm{L}^{-1} \mathrm{P}$ for $1 \mathrm{~h}$. After homogenization, filtration was conducted and the $\mathrm{P}$ concentration was determined in the equilibrium solution using the ascorbic acid method, as described by Braga and Defelipo (1972).

Data obtained from the five different areas (P25, P35, P45, AWG, and NCA) were evaluated using a $5 \times 2$ factorial design with six replications at two timepoints that represented the post-pasture cycle period (PP) and the post-soybean crop period (PC). All of the data were subjected to a normality test (Lilliefors test) and homogeneity of variances tests (Cochran and Bartlett tests). Subsequently, the results were subjected to an analysis of variance by F-test and the mean values compared by a Student t-test at the 5\% probability level using ASSISTAT software (http://www.assistat.com/).

\section{Results and Discussion}

The surface layer $(0.00-0.05 \mathrm{~m})$ had a greater LOM dry weight (LOMDW) under the low grazing treatment (P45) than in the AWG during the PP, whereas there were similar LOM values under P45 and in the NCA (Table 2). This was probably caused by high organic matter deposition (U. ruziziensis straw) on the soil surface due to the low grazing intensity and input of cattle manure. LOM consists of forms of $\mathrm{C}$ that have recently been incorporated into the soil and are not bound to soil minerals (COMPTON; BOONE, 2002), indicating active, recently incorporated SOM (GOSLING et al., 2013) that exhibits significant, short-term responses to changes in management practices (BREMER et al., 1995). Similarly, when studying soil characteristics in Montividiu-GO under CLI, NTS, and in the NCA, Loss et al. (2011) did not find any differences in LOM content between NTS and CLI areas in the 0.0-0.05 m layer. However, in the 0.05-0.10 m layer, the results were similar between the CLI and NCA areas, with higher LOM contents than the NTS area. The authors attributed these results to the high $\mathrm{C}$ content of the subsurface soil, promoted by the $U$. ruziziensis root system (LOSS et al., 2011).

The LOMDW of the areas cultivated with soybean in the $0.00-0.10 \mathrm{~m}$ layer decreased from the $\mathrm{PP}$ to the PC, while in the NCA, it increased in the 0.00-0.05 m layer and decreased in the 0.05-0.10 $m$ layer (Table 2). The LOMDW decrease in the cultivated areas was probably due to the combined effects of climate and the amount of organic residue added to the soil. $U$. ruziziensis contributed to the LOM with high $\mathrm{C} / \mathrm{N}$ ratio residues in the PP (Table 2 ), with large amounts of shoots and roots. The dry climate (low water availability and little biotic mineralization) of the PP in comparison with the PC could have contributed to the persistence of LOM in the soil. In contrast, the LOM in the cultivated areas during the PC was subjected to more intense decomposition (BIELUCZYK, 2014) because of the higher precipitation (Figure 2), and organic residues from the soybean crop, which had a lower $\mathrm{C} / \mathrm{N}$ ratio (Table 2), were incorporated into the soil. This resulted in greater $\mathrm{N}$ availability, which may have accelerated LOM mineralization and incorporation into the soil. 


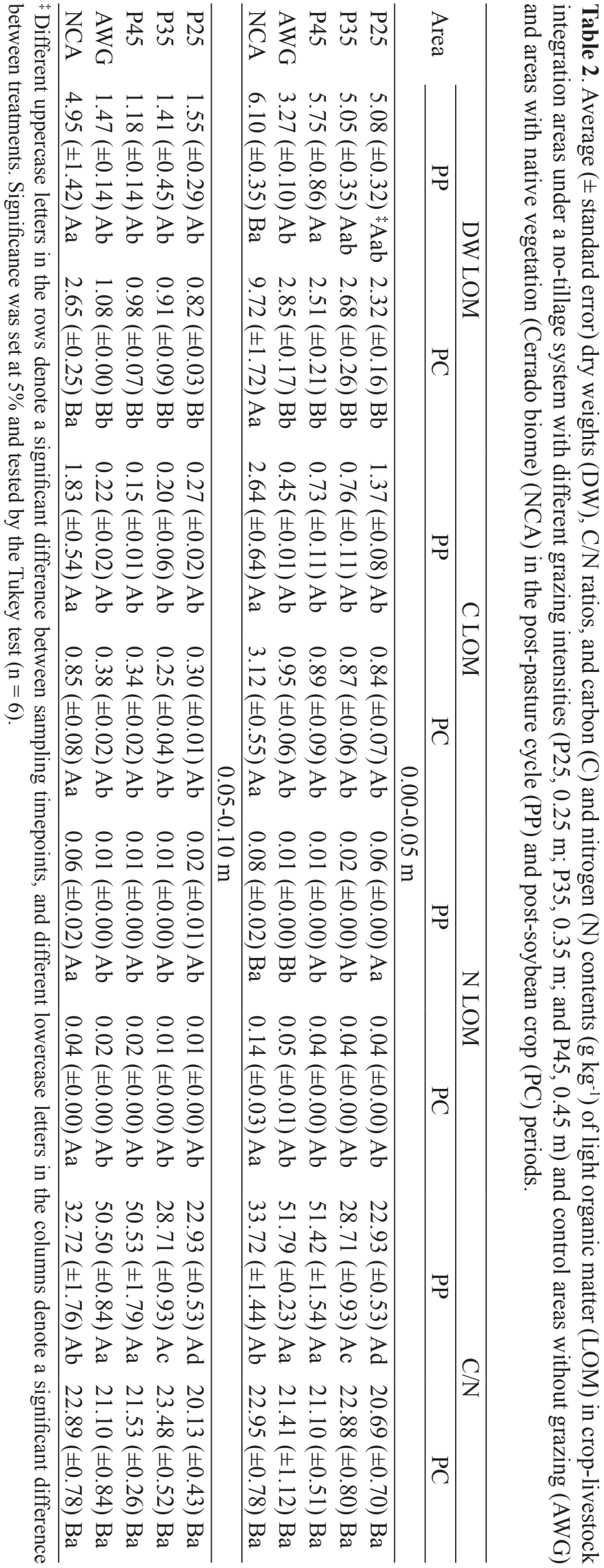

The $\mathrm{C} / \mathrm{N}$ ratio of the $\mathrm{LOM}$ in the $\mathrm{PP}$ decreased with increasing grazing intensity under the CLI system (Table 2). Because high grazing intensity increases the fractionation of residues that compose the LOM and generates greater amounts of cattle manure (that also has a low $\mathrm{C} / \mathrm{N}$ ratio), more $\mathrm{N}$ is added to the soil, which accelerates the degradation of LOM organic residues (SOUZA et al., 2009; BIELUCZYK, 2014). These factors combined increase LOM vulnerability to mineralization with the grazing intensity of the CLI. The LOM C/N ratio in the cultivated areas during the $\mathrm{PC}$ was similar to that found in the NCA in the $0.00-0.10 \mathrm{~m}$ layer (Table 2). These results highlight the importance of sampling at different times to evaluate CLI systems, and of considering seasonality and the vegetation in the analysis. Studies on the short-term effects of integrated systems should separately consider the crop and livestock periods, and in a subsequent phase, analyze them together (BIELUCZYK, 2014).

The $\mathrm{P} 25$ treatment had a higher $\mathrm{N}$ content than the other cultivated areas during the PP (Table 2). This may have been related to the high grazing intensity under this treatment, which increased the amount of cattle manure in the soil; this, in combination with pasture residues, increased the soil $\mathrm{N}$ content.

Overall, the NCA had higher LOMDW in the 0.00-0.05 m layer in the PC and 0.05-0.10 m layer in the PP and PC, $\mathrm{C}$ in the LOM in the $0.00-0.10$ $\mathrm{m}$ layer in the PP and PC, and $\mathrm{N}$ in the LOM in the $0.00-0.05 \mathrm{~m}$ layer in the $\mathrm{PC}$ and $0.05-0.10 \mathrm{~m}$ layer in the PP and PC than the cultivated areas (Table 2). This was probably because the vegetation in the NCA was adapted to the Cerrado climate and had greater stability of $\mathrm{C}$ inputs and outputs throughout the year, with no anthropic interference (GUARESCHI et al., 2012, 2016). In addition, the material that originates the LOM in the NCA is high quality, because the vegetation in the NCA is diverse and deposits organic residues of different sizes with a high lignin content onto the soil (CIANCIARUSO et al., 2006). This results in the formation of LOM with greater chemical stability than in areas 
cultivated with soybean rotation (GUARESCHI et al., 2016).

The P35 treatment (moderate grazing intensity) had the greatest RLOM in the PP, followed by the AWG and the treatments with high and low grazing intensities (Figure 3). The RLOM decreased from the PP to the PC, and there were no statistical differences between the treatments for this variable during the PC (Figure 3).

The high RLOM under treatment P35 in the PP was probably caused by greater root system development (due to cutting and grazing) than under the other treatments. Grazing changes pasture composition and increases grass root systems (SOUZA et al., 2009, 2010; MARTINS, 2013). Therefore, moderate intensity grazing may result in a better balance between shoot and root biomasses, and increase the RLOM. However, treatments P25 and P45 had unbalanced grazing intensities and lower RMOL values than the AWG. Few studies have compared RLOM values, because the process is highly labor-intensive. Despite the relatively short experiment (3 years), differences in RLOM occurred that formed the particulate fraction of $\mathrm{C}$ in the soil. Therefore, RLOM evaluations are useful in assessing short-term effects of management systems on SOM dynamics.

The decrease in the RLOM from the PP to the PC was caused by an increase in the $\mathrm{N}$ content due to the soybean residues, which may have accelerated the decomposition of the LOM fraction (GONÇALVES et al., 2010; BIELUCZYK, 2014) and resulted in no differences between the treatments.

Figure 3. Average ( \pm standard error) root dry weight in light organic matter $(\mathrm{LOM})$ in the $0.00-0.10 \mathrm{~m}$ soil layer under a crop-livestock integration system with three heights of pasture management (P25, $0.25 \mathrm{~m}$; P35, $0.35 \mathrm{~m}$; and P45, $0.45 \mathrm{~m}$ ) and control areas without grazing (AWG). Different uppercase letters denote a significant difference between sampling timepoints (post-pasture cycle and post-soybean crop), and different lowercase letters denote a significant difference between treatments. Significance was set at $5 \%$ and tested by the Tukey test $(n=6)$.

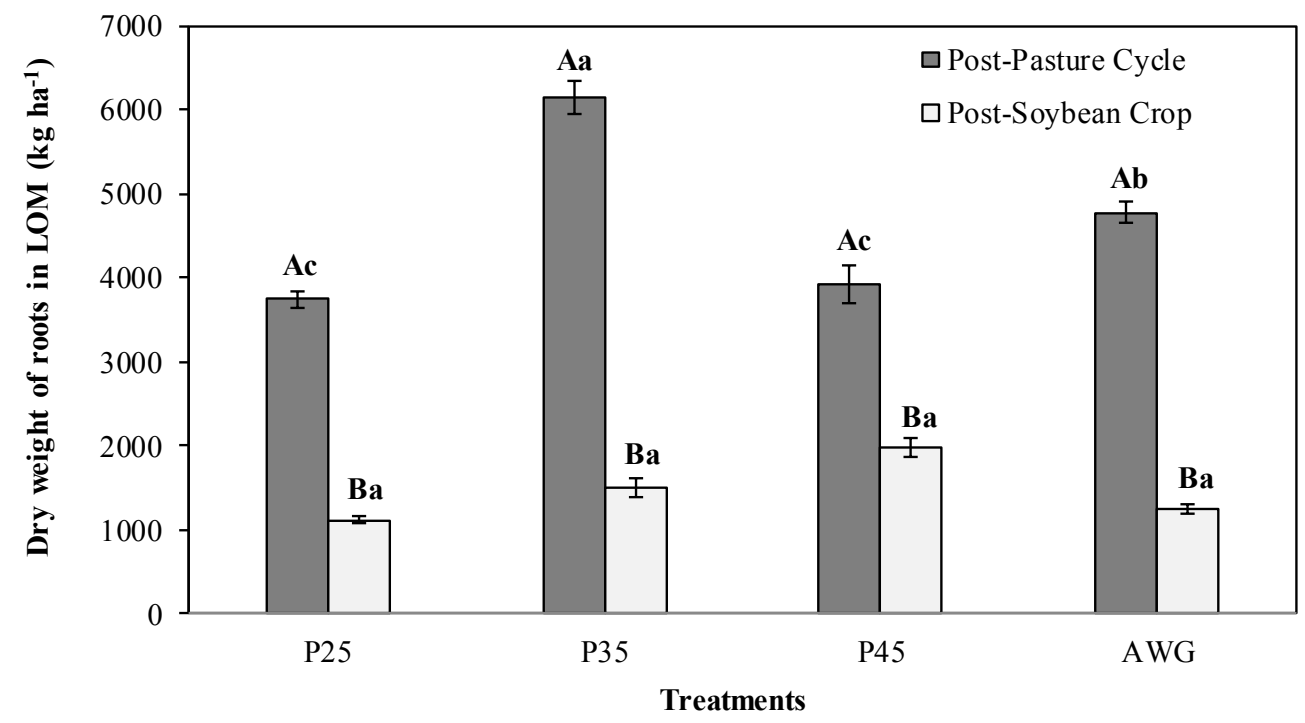


The NCA had a higher Cst than the cultivated areas at both timepoints evaluated in the 0.00 $0.20 \mathrm{~m}$ layer, but it did not differ between the cultivated areas (Table 3 ). The Cst did not differ between the PP and the PC in the 0.00-0.20 m layer (Table 3). Higher Cst values in areas with native vegetation, such as the NCA, than cultivated areas under NTS and CLI have been reported previously (GUARESCHI et al., 2012; ROSSI et al., 2012; BATISTA et al., 2013; GAZOLLA et al., 2013, 2015; BEUTLER et al., 2015). This is probably because the NCA has characteristics that promote SOM stability, such as the continuous deposition of plant residues (litterfall) and roots with different $\mathrm{C} / \mathrm{N}$ ratios, perennial vegetation, and no soil disturbance (GUARESCHI et al., 2012). The high Cst of the NCA may also be related to the short period of CLI implementation, in comparison with the many years of stability in the NCA. Therefore, CLI was not conducted for a sufficient period to stock $\mathrm{C}$ in the soil at similar levels to those in the NCA, and the area was degraded pasture before the experiment began.

The absence of statistical differences in Cst between the cultivated areas (NTS and CLI) could also be attributed to the short implementation times of the management systems, because the Cst in areas under conservation management systems require many years ( $\geq 8$ years), depending on the edaphoclimatic conditions, to recover their $\mathrm{C}$ stocks to levels close to those under the original conditions (Cerrado native vegetation) (PEREIRA NETO et al., 2007; SILVA et al., 2011; GUARESCHI et al., 2012; GAZOLLA et al., 2013). This absence of sensitivity of Cst under CLI was confirmed by the LOM results, i.e., the Cst was not affected, but some SOM compartments, such as LOM, changed, which may have influenced soil Cst dynamics, depending on how long the system had been implemented.

Overall, soil Nst was not statistically different among the treatments, except in the $0.00-0.05 \mathrm{~m}$ layer in the PC, which had higher Nst values in the NCA and P35 areas than in the other areas (Table $3)$. The Nst of the AWG decreased in the 0.00-0.05 $\mathrm{m}$ layer, while in the NCA, it increased from the PP to the PC.

The higher Nst values in the NCA than under the P25 and P45 treatments, as with the Cst values, were due to a lack of human interference in the area and the constant deposition of organic residues with different $\mathrm{C} / \mathrm{N}$ ratios, thus maintaining an environment with high stability and SOM stocks (GUARESCHI et al., 2012; ROSSI et al., 2012; BATISTA et al., 2013; GAZOLLA et al., 2013).

The higher Nst under treatment P35 than treatments P25 and P45 was probably related to its higher RLOM in the PP (Figure 3), because better root development increases nutrient cycling (COSTA et al., 2014). Souza et al. (2009) also reported higher Nst values in CLI areas with moderate grazing intensity than in those with high grazing intensity.

The reduction in Nst from the PP to the PC in the surface layer of the AWG (Table 3) may have been related to the quantity and quality $(\mathrm{C} / \mathrm{N})$ of organic residues in this area. This result was confirmed by a joint analysis of the RLOM data (Figure 3) and the $\mathrm{C} / \mathrm{N}$ ratio of the $\mathrm{LOM}$ in this treatment (Table 2), which suggested that the AWG received a large amount of plant residues with a high $\mathrm{C} / \mathrm{N}$ ratio (Table 2) from grass shoot and root (RLOM) systems. Considering that these residues were not fragmented by animals and this area had no supply of cattle manure, a liquid immobilization of $\mathrm{N}$ may have occurred. This immobilization, plus the removal of $\mathrm{N}$ by grain production, may have been responsible for the reduction in Nst in the AWG from the PP to the PC. According to Santos and Camargo (1999), this pattern is natural in areas that have recently adopted the NTS without the CLI system, i.e., $\mathrm{N}$ immobilization is greater than mineralization in the first 5 years of the NTS (early stage). 


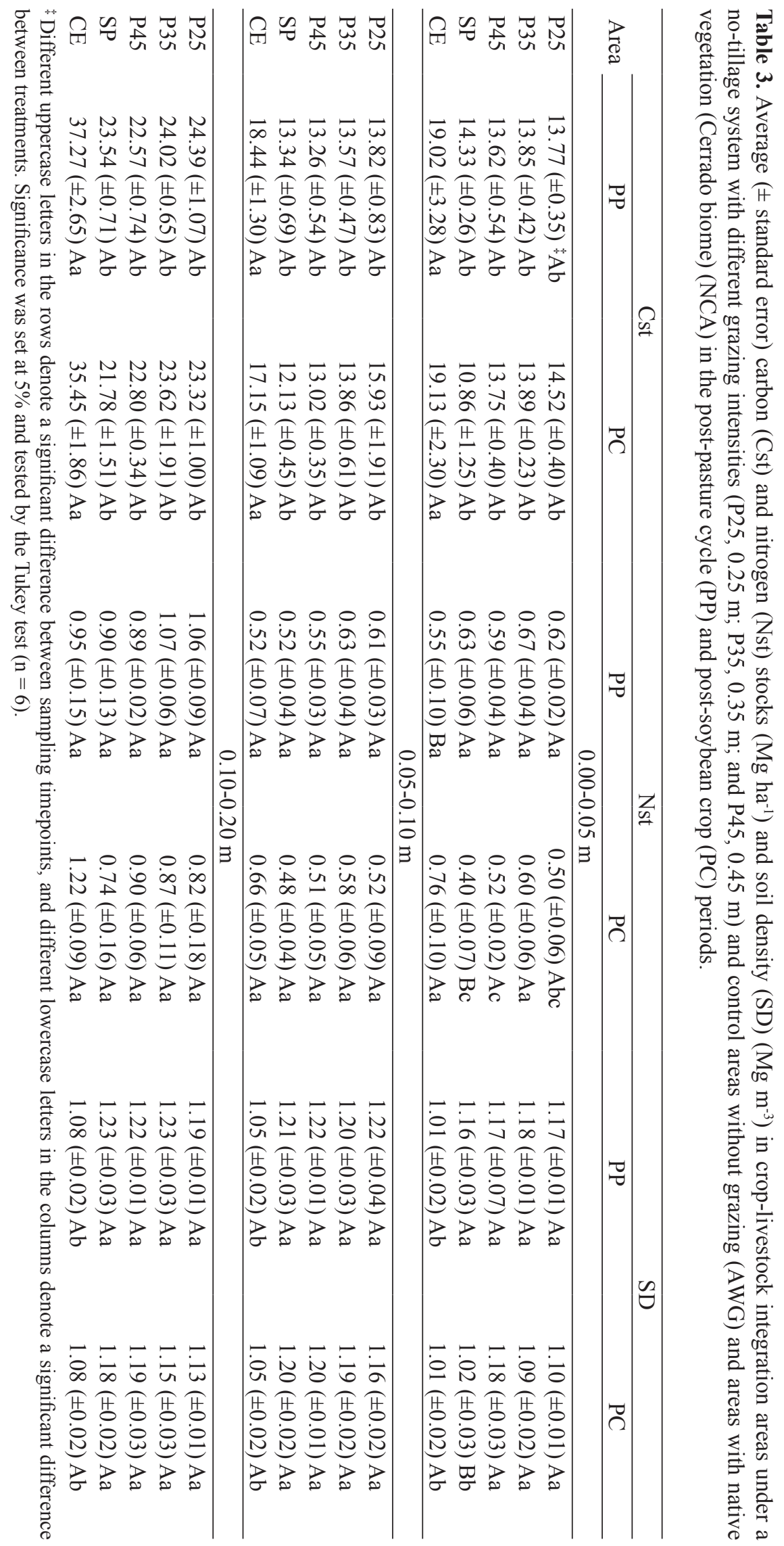


The NCA had a lower SD than the cultivated areas in the 0.00-0.05 $\mathrm{m}$ layer in the PP and the 0.05$0.20 \mathrm{~m}$ layer in the PP and the PC (Table 3), mainly because of the high $\mathrm{C}$ accumulation in these layers (Table 3) and the absence of human interference. Several previous studies have also reported this pattern (i.e., NCA with higher Cst and lower SD than NTS areas) (LOSS et al., 2011; SANTOS et al., 2011; LOSS et al., 2012b; GAZOLLA et al., 2013).

There was a decrease in the SD of the AWG from the PP to the PC in the surface layer (0.00-0.05 m), with values similar to those in the NCA and lower than those under the CLI during the PC (Table 3). The grass in the AWG contributed a considerable amount $\left(\geq 10 \mathrm{Mg} \mathrm{ha}^{-1}\right)$ of organic residue dry mass to the surface layer, and had a large amount of shoot residues in the PP due to the absence of grazing. These factors may have favored soil aggregation in the PC in the soil surface layers, which reduced the SD. According to Préchac et al. (2004), pasture used in rotation with crops performs a soil-aggregation function by improving the stability of aggregates and the physical quality of the soil because of its abundant root system. Similarly, Spera et al. (2009) reported that the accumulation of plant residues on the soil surface in the NTS favors soil aggregation and decreases the SD, depending on the time of implementation.

The fact that the AWG was not subjected to animal trampling may have contributed to its lower SD than the CLI areas with different grazing intensities (Table 3). Therefore, as reported in other studies (FLORES et al., 2007; LANZANOVA et al., 2007), grazing in CLI areas increases the SD of the surface layer (0.00-0.05 m). However, the SD of the cultivated areas was below the critical value $(>1.40$ $\mathrm{Mg} \mathrm{m}^{-3}$ ) for the development of plants in Oxisols that have clayey textures (REINERT et al., 2008). According to Conte et al. (2011), changes in SD caused by grazing in CLI areas are generally small and do not affect the root growth of cultivated plants, because pressure on the soil caused by the animals' hooves is not greater than the soil's resistance to plastic deformation (DIAS JUNIOR; PIERCE, 1996); therefore, soil aggregation can recover with time.

The NCA had a lower Prem value than the cultivated areas, regardless of soil depth or evaluation time, and no statistical differences were found among the cultivated areas for this variable (Table 4). The higher Prem in the cultivated areas than the NCA can be attributed to the liming and $\mathrm{P}$ fertilization conducted in the cultivated areas, because the application of phosphate fertilizers promotes the saturation of sites with a great affinity for $\mathrm{P}$, causing the Prem to be redistributed into fractions with weaker bonds, thereby increasing its availability to plants (SANTOS et al., 2008). Furthermore, increasing the soil $\mathrm{pH}$ by liming increases the concentration and activity of hydroxide ions in the soil solution, increases the precipitation of iron $(\mathrm{Fe})$ and aluminum (A1), reduces the formation of P-Fe and $\mathrm{P}-\mathrm{Al}$ compounds (that have low solubility), and generates negative charges by the deprotonation of hydroxyls in clays and organic matter, which causes the repulsion of phosphate to the adsorbent surface. Therefore, soil management practices that change the factors involved in these processes can reduce $P$ adsorption and increase Prem values (SOUZA et al., 2006; GUARESCHI et al., 2015). Previous studies that have reported similar results have also shown that soil management with periodic liming and phosphate fertilization reduces the maximum capacity of phosphate adsorption and increases the Prem in Oxisols under the NTS (GUPPY et al., 2005; SOUZA et al., 2006; CARNEIRO et al., 2011; GUARESCHI et al., 2012, 2015).

The fertilization and liming of the cultivated areas, the short experimental period, and the remaining Cst are the main factors that explain the absence of differences in the Prem between the treatments with different grazing intensities. 
Table 4. Average ( \pm standard error) remaining phosphorus level (Prem) in crop-livestock integration areas under a no-tillage system with different grazing intensities (P25, $0.25 \mathrm{~m} ; \mathrm{P} 35,0.35 \mathrm{~m}$; and P45, $0.45 \mathrm{~m}$ ) and control areas without grazing (AWG) and areas with native vegetation (Cerrado biome) (NCA) in the post-pasture cycle (PP) and post-soybean crop (PC) periods.

\begin{tabular}{|c|c|c|}
\hline \multirow{3}{*}{ Area } & \multicolumn{2}{|c|}{ Prem $\left(\mathrm{mg} \mathrm{kg}^{-1}\right)$} \\
\hline & $\mathrm{PP}$ & $\mathrm{PC}$ \\
\hline & \multicolumn{2}{|c|}{$0.00-0.05 \mathrm{~m}$} \\
\hline P25 & $26.59( \pm 0.33) * \mathrm{Aa}$ & $27.81( \pm 0.67) \mathrm{Aa}$ \\
\hline P35 & $26.15( \pm 0.96) \mathrm{Aa}$ & $26.35( \pm 0.65) \mathrm{Aa}$ \\
\hline P45 & $27.33( \pm 0.68) \mathrm{Aa}$ & $27.47( \pm 0.49) \mathrm{Aa}$ \\
\hline AWG & $27.65( \pm 1.92) \mathrm{Aa}$ & $26.40( \pm 0.51) \mathrm{Aa}$ \\
\hline \multirow[t]{2}{*}{ NCA } & $22.62( \pm 0.72) \mathrm{Ab}$ & $23.83( \pm 1.23) \mathrm{Ab}$ \\
\hline & \multicolumn{2}{|c|}{$0.05-0.10 \mathrm{~m}$} \\
\hline P25 & $24.09( \pm 0.70) \mathrm{Aa}$ & $25.31( \pm 0.54) \mathrm{Aa}$ \\
\hline P35 & $24.43( \pm 0.61) \mathrm{Aa}$ & $23.96( \pm 0.26) \mathrm{Aa}$ \\
\hline $\mathrm{P} 45$ & $24.58( \pm 0.51) \mathrm{Aa}$ & $25.97( \pm 0.49) \mathrm{Aa}$ \\
\hline AWG & $24.78( \pm 0.79) \mathrm{Aa}$ & $24.54( \pm 0.15) \mathrm{Aa}$ \\
\hline \multirow[t]{2}{*}{ NCA } & $20.75( \pm 0.39) \mathrm{Ab}$ & $21.41( \pm 0.77) \mathrm{Ab}$ \\
\hline & \multicolumn{2}{|c|}{$0.10-0.20 \mathrm{~m}$} \\
\hline P25 & $21.34( \pm 0.25) \mathrm{Aa}$ & $23.68( \pm 0.19) \mathrm{Aa}$ \\
\hline P35 & $24.37( \pm 1.34) \mathrm{Aa}$ & $24.36( \pm 1.10) \mathrm{Aa}$ \\
\hline $\mathrm{P} 45$ & $23.29( \pm 0.60) \mathrm{Aa}$ & $23.17( \pm 0.46) \mathrm{Aa}$ \\
\hline AWG & $22.52( \pm 0.66) \mathrm{Aa}$ & $22.24( \pm 0.41) \mathrm{Aa}$ \\
\hline $\mathrm{NCA}$ & $19.07( \pm 0.85) \mathrm{Ab}$ & $21.61( \pm 0.71) \mathrm{Ab}$ \\
\hline
\end{tabular}

ॠDifferent uppercase letters in the rows denote a significant difference between sampling timepoints, and different lowercase letters in the columns denote a significant difference between treatments. Significance was set at $5 \%$ and tested by the Tukey test $(n=6)$.

\section{Conclusions}

Despite the short implementation time, the moderate grazing treatment (P35) under the CLI system gave the most promising results for nutrient cycling, by increasing the soil Nst and RLOM content in the PP. The absence of grazing in the NTS area reduced the SD from the PP to the PC, while the treatments with different grazing intensities had similar values throughout this period. The results obtained in the cultivated areas, i.e., high LOMDW in the P45 treatment, high Nst and RLOM values in P35, and similar Cst and Prem values in areas with and without grazing, suggest that production could be intensified under low and moderate grazing intensities in the CLI system.

\section{References}

ALVAREZ, V.; V. H.; NOVAIS, R. F.; DIAS, L. E.; OLIVEIRA, J. A. Determinação e uso do fósforo remanescente. Boletim Informativo da Sociedade Brasileira de Ciência do Solo, Viçosa, v. 25, n. 1, p. 2732, 2000.

ANDERSON, J. N.; INGRAM, J. S. I. Tropical soil biology and fertility: a handbook of methods. Wallingford: CAB International, 1989. $171 \mathrm{p}$.

BATISTA, I.; CORREIA, M. E. F.; PEREIRA, M. G.; BIELUCZYK, W.; SCHIAVO, J. A.; MELLO, N. A. de; ROWS, J. R. C. Teores e estoque de carbono em frações lábeis e recalcitrantes da matéria orgânica do solo sob integração lavoura-pecuária no bioma Cerrado. Semina: Ciências Agrárias, Londrina, v. 34, n. 6, p. 3377-3388, 2013.

BEUTLER, S. J.; PEREIRA, M. G.; LOSS, A.; PERIN, A.; ANJOS, L. H. C. Humic substances and phosphorus fractions in areas with crop-livestock integration, pasture and natural cerrado vegetation in Goiás, Brazil. Tropical and Subtropical Agroecosystems, Yucatán, v. 18, n. 1, p. 11-25, 2015. 
BEZERRA, R. P. M.; LOSS, A.; PEREIRA, M. G.; PERIN, A. Frações de fósforo e correlação com atributos edáficos sob sistemas de plantio direto e integração lavoura-pecuária no Cerrado Goiano. Semina: Ciências Agrárias, Londrina, v. 36, n. 3, p. 1287-1306, 2015.

BIELUCZYK, W. Atributos edáficos e agronômicos em sistema de integração lavoura-pecuária sob intensidades de pastejo em plantio direto no cerrado goiano. 2014. Dissertação (Mestrado em Agronomia - Ciência do Solo) - Universidade Federal Rural do Rio de Janeiro, Seropédica.

BONETTI, J. A.; PAUlinO, H. B.; SOUZA, E. D.; CARNEIRO, M. A. C.; SILVA, G. N. Influência do sistema integrado de produção agropecuária no solo e na produtividade de soja e braquiária. Pesquisa Agropecuária Tropical, Goiânia, v. 45, n. 1, p. 104-112, 2015 .

BRAGA, J. M.; DEFELIPO, B. V. Relações entre formas de fósforo inorgânico, fósforo disponível e material vegetal em solos sob vegetação de cerrado: I - Trabalhos de laboratório. Revista Ceres, Viçosa, MG, v. 19, n. 1, p. 124-136, 1972.

BREMER, E.; ELLERT, B. H.; JANZEN, H. H. Total and light-fraction carbon dynamics durig four decades after cropping changes. Soil Science Society of America Jounal, Madison, v. 59, n. 1, p. 1398-1403, 1995.

CAMARGO, M. S.; BARBOSA, C. S.; RESENDE, R. E.; KORNDÖRFER, G. E.; PEREIRA, H. S. Fósforo em solos de cerrado submetidos a calagem. Bioscience Journal, Uberlândia, v. 26, n. 2, p. 187-194, 2010.

CARNEIRO, L. F.; RESENDE, A. V.; FURTINI NETO, A. E.; SANTOS, J. Z. L.; CURI, N.; REIS, T. H. P.; VALLE, L. A. R. Frações de fósforo no solo em resposta à adubação fosfatada em um latossolo com diferentes históricos de uso. Revista Brasileira de Ciência do Solo, Viçosa, MG, v. 35, n. 2, p. 483-491, 2011.

CARVALHO, P. C. de F.; ANGHINONI, I.; MORAES, A. de; SOUZA, E. D. de; SULC, R. M.; LANG, C. R.; FLORES, J. P.; LOPES, M. L. T.; SILVA, J. L. da; CONTE, O.; WESP, C. de L.; LEVIEN, R.; FONTANELI, C. B. Managing grazing animals to achieve nutrient cycling and soil improvement in no-till integrated systems. Nutrient Cycling in Agroecosystems, Dordrecht, v. 88, n. 2, p. 259-273, 2010.

CIANCIARUSO, M. V.; PIRES, J. S. R.; DELITTI, W. B. C.; SILVA, E. F. L. P. Produção de serapilheira e decomposição do material foliar em um cerradão na Estação Ecológica de Jataí, município de Luiz Antônio, SP, Brasil. Acta Botânica Brasileira, Belo Horizonte, v. 20, n. 1, p. 49-59, 2006.
COMPTON, J. E.; BOONE, R. D. Soil nitrogen transformations and the role of light fraction organic matter in forest soils. Soil Biology and Biochemistry, Oxford, v. 34, n. 7, p. 933-943, 2002.

CONTE, O.; FLORES, J. P. C.; CASSOL, L. C.; ANGHINONI, I.; CARVALHO, P. C. F.; LEVIEN, R.; WESP, C. L. Evolução de atributos físicos de solo em sistema de integração lavoura pecuária. Pesquisa Agropecuária Brasileira, Brasília, v. 46, n. 10, p. 13011309, 2011.

COSTA, S. E. V. G. A.; SOUZA, E. D.; ANGHINONI, I.; CARVALHO, P. C. F.; MARTINS, A. P.; KUNRATH, T. R.; CECAGNO, D.; BALERINI, F. Impact of an integrated no-till crop-livestock system on phosphorus distribution, availability and stock. Agriculture, Ecosystems and Environment, Amsterdam, v. 190, n. 1, p. 43-51, 2014.

DIAS JUNIOR, M. S.; PIERCE, F. J. O processo de compactação do solo e sua modelagem. Revista Brasileira de Ciência do Solo, Viçosa, MG, v. 20, n. 2, p. 175-182, 1996.

DONAGEMA, G. K.; CAMPOS, D. V. B. de; CALDERANO, S. B.; TEIXEIRA, W. G.; VIANA, J. H. M. (Org.). Manual de métodos de análise de solos. 2. ed. Rio de Janeiro: Embrapa Solos, 2011. 230 p.

EMPRESA BRASILEIRA DE PESQUISA AGROPECUÁRIA - EMBRAPA. Sistema brasileiro de classificação de solos. 3. ed. Rio de Janeiro: Embrapa Solos, 2013. 353 p.

FLORES, J. P. C.; ANGHINONI, I.; CASSOL, L. C.; CARVALHO, P. C. F.; LEITE, J. G. D. B.; FRAGA, T. I. Atributos físicos do solo e rendimento de soja em sistema plantio direto em integração lavoura pecuária com diferentes pressões de pastejo. Revista Brasileira de Ciência do Solo, Viçosa, MG, v. 31, n. 4, p. 771-780, 2007.

GAZOLLA, P. R.; GUARESCHI, R. F.; PERIN, A. Estoque de carbono e atributos físicos de um Latossolo Vermelho em diferentes sistemas de manejo. Revista Brasileira de Ciências Agrárias, Recife, v. 8, n. 2, p. 229235, 2013.

GAZOLLA, P. R.; GUARESCHI, R. F.; PERIN, A.; PEREIRA, M. G.; ROSSI, C. Q. Frações da matéria orgânica do solo sob pastagem, sistema plantio direto e integração lavoura-pecuária. Semina: Ciências Agrárias, Londrina, v. 36, n. 2, p. 693-704, 2015. 
GONÇALVES, S. L.; SARAIVA, O. F.; FRANCHINI, J. C.; TORRES, E. Decomposição de resíduos de milho e soja em função do tempo e do manejo do solo. Londrina: Embrapa Soja, 2010. 19 p. (Boletim de Pesquisa e Desenvolvimento, n. 3).

GOSLING, P.; PARSONS, N.; BENDING, G. D. What are the primary factors controlling the light fraction and particulate soil organic matter content of agricultural soils? Biology and Fertility of Soils, Firenze, v. 49, n. 8, p. 1001-1014, 2013.

GUARESCHI, R. F.; PEREIRA, M. G.; PERIN, A. Adsorption of $\mathrm{P}$ and forms of iron in no-tillage areas in the Cerrado biome. Acta Scientiarum. Agronomy, Maringá, v. 37, n. 1, p. 109-116, jan./mar. 2015.

Deposição de resíduos vegetais, matéria orgânica leve, estoques de carbono e nitrogênio e fósforo remanescente sob diferentes sistemas de manejo no cerrado goiano. Revista Brasileira de Ciência do Solo, Viçosa, MG, v. 36, n. 3, p. 909-920, 2012.

. Fracionamento densimétrico da matéria orgânica em uma cronossequência de agricultura em áreas de plantio direto no Cerrado. Semina: Ciências Agrárias, Londrina, v. 37, n. 2, p. 595-610, 2016.

GUPPY, C. N.; MENZIES, N. W.; MOODY, P. W.; BLAMEY, F. P. C. Competitive sorption reactions between phosphorus and organic matter in soil: a review. Australian Journal of Soil Research, Collingwood, v. 43, n. 2, p. 189-202, 2005.

LANZANOVA, M. E.; NICOLOSO, R. S.; LOVATO, T.; ELTZ, F. L. F.; AMADO, T. J. C.; REINERT, D. J. Atributos físicos do solo em sistema de integração lavoura-pecuária sob plantio direto. Revista Brasileira de Ciência do Solo, Viçosa, MG, v. 31, n. 5, p. 1131-1140, 2007.

LEMAIRE, G.; FRANZLUEBBERS, A.; CARVALHO, P. C. F.; DEDIEU, B. Integrated croplivestock systems: strategies to achieve synergy between agricultural production and environmental quality. Agriculture, Ecosystems \& Environment, Amsterdam, v. 190, p. 4-8, 2014.

LOSS, A.; PEREIRA, M. G.; BEUTLER, S. J.; PERIN, A.; ANJOS, L. H. C. Carbon, nitrogen and natural abundance of $\delta 13 \mathrm{C}$ e $\delta 15 \mathrm{~N}$ of light fraction Organic matter under no-tillage and crop-livestock Integration systems. Acta Scientiarum Agronomy, Maringá, v. 34, n. 4, p. 465-472, 2012a.

Densidade e fertilidade do solo sob sistemas de plantio direto e de integração lavoura-pecuária no cerrado. Revista Ciências Agrárias, Belém, v. 55, n. 4, p. 260-268, 2012c.
LOSS, A.; PEREIRA, M. G.; GIÁCOMO, S. G.; PERIN, A.; ANJOS, L. H. C. Agregação, carbono e nitrogênio em agregados do solo sob plantio direto com integração lavoura-pecuária. Pesquisa Agropecuária Brasileira, Brasília, v. 46, n. 10, p. 1269-1276, 2011.

LOSS, A.; PEREIRA, M. G.; PERIN, A.; COUTINHO, F. S.; ANJOS, L. H. C. Particulate organic matter in soil under different management systems in the Brazilian Cerrado. Soil Research, Clayton, v. 50, n. 8, p. 685-693, 2012b.

MARTINS, A. P. Acidez do solo e reaplicação de calcário em sistema de integração lavoura-pecuária em plantio direto. 2013. Dissertação (Mestrado em Ciência do Solo) - Universidade Federal do Rio Grande do Sul, Santa Maria.

PEREIRA NETO, O. C.; GUIMARÃES, M. D. F.; RALISCH, R.; FONSECA, I. C. Análise do tempo de consolidação do sistema de plantio direto. Revista Brasileira de Engenharia Agrícola e Ambiental, Campina Grande, v. 11, n. 5, p. 489-496, 2007.

PRÉCHAC, F. G.; ERNST, O.; SIRI-PRIETO, G.; TERRA, J. A. Integrating no-till into crop-pasture rotations in Uruguai. Soil and Tillage Research, Amsterdam, v. 77, n. 1, p. 1-13, 2004.

REINERT, D. J.; ALBUQUERQUE, J. A.; REICHERT, J. M.; AITA, C.; ANDRADA, M. M. C. Limites críticos de densidade do solo para o crescimento de raízes de plantas de cobertura em argissolo vermelho. Revista Brasileira de Ciência do Solo, Viçosa, MG, v. 32, n. 5, p. 1805-1816, 2008.

ROSSI, C. Q.; PEREIRA, M. G.; GIÁCOMO, S. G.; BETTA, M.; POLIDORO, J. C. Frações lábeis da matéria orgânica em sistema de cultivo com palha de braquiária e sorgo. Revista Ciência Agronômica, Fortaleza, v. 43, n. 1, p. 38-46, 2012.

SALTON, J. C.; MERCANTE, F. M.; TOMAZI, M.; ZANATTA, J. A.; CONCENÇO, G.; SILVA, W. M.; RETORE, M. Integrated crop-livestock system in tropical Brazil: toward a sustainable production system. Agriculture, Ecosystems \& Environment, Amsterdam, v. 190, p. 70-79, 2014.

SANTOS, G. A.; CAMARGO, F. A. O. Fundamentos da matéria orgânica do solo: ecossistemas tropicais e subtropicais. Porto Alegre: Ed. Genesis, 1999. 508 p.

SANTOS, G. G.; MARCHÃO, R. L.; SILVA, E. M.; SILVEIRA, P. M.; BECQUER, T. Qualidade física do solo sob sistemas de integração lavoura-pecuária. Pesquisa Agropecuária Brasileira, Brasília, v. 46, n. 10, p. 1339-1348, 2011. 
SANTOS, J. Z. L.; FURTINI NETO, A. E.; RESENDE, A. V.; CURI, N.; CARNEIRO, L. F.; COSTA, S. E. V. G. A. Frações de fósforo em solo adubado com fosfatos em diferentes modos de aplicação e cultivado com milho. Revista Brasileira de Ciência do Solo, Viçosa, MG, v. 32, n. 2, p. 705-714, 2008.

SILVA, E. F.; LOURENTE, E. P. R.; MARCHETTI, M. E.; MERCANTE, F. M.; FERREIRA, A. K. T.; FUJII, G. C. Frações lábeis e recalcitrantes da matéria orgânica em solos sob integração lavoura-pecuária. Pesquisa Agropecuária Brasileira, Brasília, v. 46, n. 10, p. 13211331, 2011.

SISTI, C. P. J.; SANTOS, H. P. dos; KOHHANN, R.; ALVES, B. J. R.; URQUIAGA, S.; BODDEY, R. M. Change in carbon and nitrogen stocks in soil under 13 years of conventional or zero tillage in southern Brazil. Soil and Tillage Research, Amsterdam, v. 76, n. 1, p. 3958, 2004.

SOUZA, E. D.; COSTA, S. E. V. G. de A.; ANGHINONI, I.; CARVALHO, P. C. de F.; ANDRIGUETI, M.; CAIO, E. Estoque de carbono orgânico e de nitrogênio no solo em sistema de integração lavoura-pecuária em plantio direto, submetido a intensidades de pastejo. Revista Brasileira de Ciência do Solo, Viçosa, MG, v. 33, n. 6, p. 1829-1836, 2009.
SOUZA, E. D. de; COSTA, S. E. V. G. de A.; ANGHINONI, I.; CARVALHO, P. C. de F.; OLIVEIRA, E. V. F. de; MARTINS, A. P.; CAO, E.; ANDRIGHETTI, M. Soil aggregation in a crop-livestock integration system under no-tillage. Revista Brasileira de Ciência do Solo, Viçosa, MG, v. 34, n. 4, p. 1362-1374, 2010.

SOUZA, R. F.; FAQUIN, V.; TORRES, P. R. F.; BALIZA, D. P. Calagem e adubação orgânica: influência na adsorção de fósforo em solos. Revista Brasileira de Ciência do Solo, Viçosa, MG, v. 30, n. 6, p. 975-983, 2006.

SPERA, S. T.; SANTOS, H. P. dos; FONTANELI, R. S.; TOMM, G. O. Integração lavoura e pecuária e os atributos físicos de solo manejado sob sistema plantio direto. Revista Brasileira de Ciência do Solo, Viçosa, MG, v. 33, n. 1, p. 129-136, 2009.

VALLADARES, G. S.; PEREIRA, M. G.; ANJOS, L. H. C. Adsorção de fósforo em solos de argila de atividade baixa. Bragantia, Campinas, v. 62, n. 1, p. 111-118, 2003. 